\title{
Preservation of labour potential in the Ukrainian healthcare sector: on the way to the third SDG fulfilment in pandemic conditions
}

\author{
Lyubomyr Sopilnyk, Viktoriia Dotsenko**, Birute Aleksandraviciute ${ }^{* * *}$
}

\author{
Received: 2021-09-01 \\ Accepted: 2021-10-29 \\ DOI: http://doi.org/10.46489/lbsh.2021-1-3-3
}

\begin{abstract}
In this article, we explored the labour potential of health care in Ukraine. We noted the unique role of conservation and development of labour potential given the conditions of the pandemic. We focused on the goals and values of sustainable development. We emphasized that the improvement of health workforce policies will allow Ukraine to move closer to implementing the third SDG. In this study, we have described at the theoretical level possible areas for improving policies on medical education, preventing labour migration of medical staff, improving motivation methods, ensuring customer focus and transparency of services. As a result, we proposed discussing several organizational and economic principles of growth and preservation of labour potential. This study can be helpful to governments in developing countries looking for new ways to improve health care.
\end{abstract}

Keywords: sustainable development, the third goal of sustainable development, medical sector, labor potential, medical staff.

\footnotetext{
* Lyubomyr Sopilnyk, D.Sc. (Law), D.Sc. (Engineering), Professor, Professor of the Department of Economic and Legal Disciplines, Lviv University of Business and Law, 99 Kulparkivska Str., Lviv, 79021, Ukraine, sopilnyk01@gmail.com, ORCID: http://orcid.org/0000-0001-6581-7255 (corresponding author).

** Viktoriia Dotsenko, PhD, independent, ORCID: https://orcid.org/0000-0002-2653-767X

${ }^{* * *}$ Birute Aleksandraviciute, Doctor, Affiliate professor, Mykolas Romeris University, Faculty of Public Governance and Business, Institute of Leadership and Strategic Management, Ateities st. 20 LT-08303 Vilnius, Lithuania; ORCID:

https://orcid.org/0000-0003-2819-1315
} 


\section{INTRODUCTION}

The third goal of sustainable development is to "Ensure healthy lives and promote wellbeing for all at all ages." Effective strengthening of the organizational support for the effective functioning of the health care system for sustainable development is possible only if the formation, development and implementation of labour-capital in this area are adequate. In turn, implementing organizational and economic principles for improving investment mechanisms to ensure the proper health care in Ukraine depends on the staffing of health care reform processes and relies on labour potential.

Improving investment mechanisms to ensure adequate health care is expected to expand the technical and technological potential of the sector. At the same time, updating the material and technical base, the use of innovative technological advances in health care requires highly qualified personnel. Further reform of the sphere will depend entirely on the availability of appropriate labour potential, including management and staffing.

The issue of healthcare staffing has always been of high importance. Among the recent publications that influenced our decision to write this article was the book Health Capital and Sustainable Socioeconomic Development (Cholewka \& Motlagh (Eds.), 2008), where we saw clear parallels between sustainable development and the state of health care supply. Ukraine is still a developing country, so that we can apply the general principles outlined by Harpham, T., \& Werna, E. (1996). In the context of a global pandemic, we pay attention to the potential for integrating the Ukrainian health care system into the world (Cordell, 2011). Recognition and acceptance of the game's rules in a globalized society is an essential step for global prosperity and sustainable development (Martens, 2006).

Sustainable health researchers pay much attention to issues that only partially cover work potential (Mackay, 2013). This is due to specific differences in the formation of the labour potential of health care in Ukraine and other developing countries (Fadhlurrohman, 2020). Also, research on health governance often focuses on national policies, which distracts from the problems of labour provision (Reshetnikov, 2018).
Thus, this article aims to justify ways to preserve the labour potential in health care, taking into account the specifics of Ukrainian policy in this area.

\section{METHODS}

This article is part of the theoretical framework of sustainable development (Dugani, 2016). We have drawn attention to the fact that healthcare workers are incredibly vulnerable in the context of the coronavirus pandemic in Ukraine. To ensure sustainable development to improve the efficiency of health care in Ukraine, we conducted a theoretical study and summarized possible ways to preserve labour potential.

A comprehensive solution to the existing problems depends on the introduction of an organizational and economic mechanisms for the development of labour-capital in the field of health care, which should cover the following aspects:

- improving the system of medical education and employment;

- control of intersectoral and interstate migration of medical staff;

- improving the designs of remuneration and motivation in the field of health care;

- introduction of customer orientation;

- increasing the transparency of the sphere.

In this article, we have analyzed numerous scientific sources and briefly summarized each of the areas. As a result, we have formed a set of organizational and economic principles for developing and preserving the labour potential of health care in a pandemic in Ukraine. In this way, we have achieved the goal of creating high-level goals (Singer, 2007) for the Ukrainian government in health care.

\section{RESULTS}

\section{Improving the system of medical education and employment}

The system of higher medical education in Ukraine has significant development potential (Kulichenko, 2021). This is confirmed by the demand for graduates of domestic universities in medical institutions of other countries and the involvement of international students. At the same time, the management of the labour potential of the sphere based on sustainable 
development involves the implementation of long-term preservation of personnel from their laundering abroad and employment of gifted youth on the basis of social justice, decent pay and working conditions. The implementation of this thesis will be facilitated by a change in the approach to training and employment of health workers.

The medical education system is a country resource that can and should be used for economic, social, political and cultural purposes (Bodur, 2002). Strategic directions of reorganization of the domestic system of higher medical and pharmaceutical education are determined by domestic processes and global development trends (Ono, 2012). Thus provide for its structure, content and quality in line with national needs and requirements of the health care system and international standards.

Comparing the professional training of doctors in higher education institutions in Poland and Ukraine, Khomenko, K. P. notes that some experience of Polish medical universities is crucial for training of medical staff in Ukraine: to improve the content (increase the share of variable component and strengthen the practical part); to introduce innovative technologies of professional training of doctors; give higher medical education more autonomy; to increase the role of the Association of Physicians of Ukraine in the process of licensing and accreditation of higher medical, educational institutions and the implementation of postgraduate education (Khomenko, 2015). Along with this, Liakhovskyi V., et al. note that the purpose and objectives of the Bologna Process, which is aimed at forming a single European educational space, are a means of improving its quality and providing qualified personnel in the European labour market. However, scientists are convinced that these principles do not always meet the interests of the Ukrainian labour market, sometimes contradicting the tradition of training for decades. That is why we consider it appropriate to implement legal and educational measures to take into account national interests, preserve the traditions of national education, and the achievements of domestic scientific thought (Liakhovskyi, 2012).

\section{Control of intersectoral and interstate migration of medical staff}

Only based on improving investment mechanisms for the development of health care is it possible to finally address the issue of largescale labour migration, which is a threat to sustainable development (Bachmann, 2021). At the same time, as mentioned earlier, the full implementation of such mechanisms is possible only based on staffing in the appropriate number and with sufficient qualifications and experience. The difficult political and socioeconomic situation in the country does not allow for attracting foreign personnel, as highly qualified workers can not agree to the wages currently offered by the market. Thus, it is expedient to create intermediate mechanisms to prevent the health sector's intersectoral and interstate migration of labour potential (Hjelm, 2012).

The migration policy of highly developed countries is aimed at attracting immigrants (Hercog, 2018), including and Ukrainians, which contributes to increased migration. However, all the measures of foreign countries will not be important for the Ukrainian emigrant if he has prospects in the homeland as an alternative. If, after the stabilization of the political situation in Ukraine, the country's economy develops in such a way that Ukrainian migrants will be able to receive decent wages to provide normal living conditions for their families, social guarantees, favorable conditions for doing business, they will not need to look for low-skilled work or work with a high level of injuries abroad.

It is advisable to start overcoming labour migration by establishing a dialogue with the part of the labour potential of the health sector prone to migration. The first step in this challenging path should be to identify the appropriate circle of people. The complexity of the process is that information about a person's intentions to migrate is private. Willingness to share such information is possible if the person is not subject to any restrictions on their employment or civil rights (Chauvin, 2013).

To solve this problem, we offer open professional information resources on the Internet for students of medical universities and medical staff. Furthermore, in the functionality of the relevant resources, we propose to include 
the possibility of anonymous surveys to determine the number, personal qualities, views and beliefs of persons prone to labour migration. Therefore, by posting motivational materials and further analyzing the results of surveys and making specific management decisions, it will be possible to work directly with groups interested in migration, which will ultimately improve the outflow of personnel to other industries and abroad. Of course, detached from the improvement of investment mechanisms for financing health care, such a system will not work effectively (Sepetis, A. 2020), but its potential to clarify ways to respond to threats of downsizing is undeniable.

The opportunities that will open up in connection with the establishment of contacts with migrant workers working in other countries should also be noted. Of particular importance for the booming health reform, the Ukrainian government should consider the experience of working in foreign medical institutions. Given this, policies should be based on monitoring, information and motivational work in three areas: working with students and graduates of medical universities, working with medical staff who are thinking about the prospects of labour migration, and working with migrant workers in Ukraine's interest in returning the latter. Regarding the latter, let us also mention the results of the analytical study "Migration as a factor in development in Ukraine". In terms of age, the probability of return is directly proportional to the age of migrant workers: the older the migrant, the more likely they are to return home. This conclusion makes sense because older migrant workers are more likely to have achieved their primary migration goals. Other factors motivate them to return home includes health problems or an inability to adapt to changing labour market conditions in destination countries (Mizhnlabouryi tsentr perspektyvnykh doslidzhen, 2006).

Foreign policy to support compatriots abroad, including on the territory of Ukraine, contributes to the loss of Ukraine's citizens in the event of a worse economic situation than in neighbouring countries. Unfortunately, in Ukraine, unlike in many countries, the resource of repatriation of compatriots is not used enough. Although assistance has been repeatedly declared as one of the priorities of migration policy, there was no law defining the status of repatriates, and no state aid was provided for repatriation and resettlement in the homeland.

Recognizing that there are still many unresolved issues in the return of migrant workers to low-income countries (Motlhatlhedi, 2018), we emphasize the importance of pretraining, communication channels and monitoring of the real state of affairs regarding the labour potential of health care.

Government should inform stakeholders about migration, its prospects and shortcomings based on transparency and partnership. At the same time, creating the preconditions for the return of international and intersectoral migrants involves establishing communication channels and streamlining the information they should receive. Significant in this regard is the increasing improvement of mechanisms for motivating and stimulating health professionals with the immediate reflection of progress in the relevant information systems.

\section{Improving the designs of remuneration and motivation in the field of health care}

Motivation can take both financial and non-financial ways. According to the law, medical workers are not provided with the payment of material assistance to address social issues, allowances for the prestige of work, monetary remuneration for conscientious work and exemplary performance of duties, etc. As a result, the wages of health care workers are one of the lowest among workers in other sectors of the economy and are in the penultimate place before agriculture (Shevchuk, 2014).

The urgency of improving the mechanisms of work motivation in the context of sustainable social development is confirmed by the fact that the unwillingness to be interested in novelties in the scientific literature at their own expense, attend conferences at their own cost, engage in professional development leads to low levels of medical care in Ukraine. Furthermore, raising salaries will not promote the use of additional money for professional growth, as the new salaries of medical workers 
only raise wages in medicine to average earnings (Chernenko, 2013).

Thus, we recommend intensifying work on developing a single rating system for health professionals in the context of cooperation between research institutions and medical institutions. Foreign experience will also be helpful in this process, and it is proposed to involve them with the involvement of professional labour migrants. Approbation and widespread implementation of the relevant system will contribute to a long-term increase in the motivation of health professionals, which will have a positive impact on the effectiveness of health care and contribute to the goals of sustainable development. In addition, improving approaches to managing incentive and incentive systems will increase the likelihood of migrant workers returning and prevent the threat of staff shortages in health care.

Undoubtedly, given the leading role of the material factor and the cost of developing a national rating system, it will be necessary to ensure the initial expenditures from the state budget. However, as they gain credibility with the appropriate rating, they are convinced of the significant potential for attracting investment in this area. In addition, the objective indicators of the rating will in themselves contribute to the intangible incentives of material workers, the emergence of a spirit of competition.

\section{Introduction of customer orientation and increasing the transparency of the sphere}

Management activities for the implementation of customer orientation should be based on and include both CRM components and, in part, components of mass customization: customer integration: flexibility in customer request, flexibility in product offerings, communication mechanisms, quality information system, sound design; customer relationship management through CRMrelationships of financial, marketing and information technology, which is best expressed in software products, optimization of the system of factors in the process of providing services (Rudiuk, 2013).
One of the central factors in the unpopularity of the customer-oriented approach in state and municipal health care facilities is the lack of competition and transparent incentives. The introduction of a national rating system may partially change the outlined situation.

The introduction of customer-oriented practices should be based on investment and improvement of management methods (Chen, 2021). However, with a clear understanding of the subjects of managerial influence (Ministry of Health, regional state administration) of the strategic key indicators to be achieved, a slight improvement of the service component can be achieved in a short time by improving communication channels, improving mechanisms for responding to complaints. An important area of work is conducting ethical training among health professionals. At such training, it is expedient to analyze the most common conflict situations that arise in working with clients, ways to overcome them, ways to establish communication, and the ability to help in medical terms and organizational and moral. An additional guarantee of customer orientation should be the development of integrated information systems.

Comprehensive provision of a clientoriented approach will increase the medical profession's authority, which is one of the essential intangible factors of medical staff, and therefore - will help curb labour migration.

As already mentioned, most of the areas for achieving efficiency in managing human resources in the health sector are systematically related. Recognizing the crucial role of funding for the industry, we can assume that achieving efficiency and sustainable development will be difficult even with a considerable increase in the health budget. The unifying factor of both the improvement of investment mechanisms and the mechanisms of action and preservation of labour potential should be the provision of maximum transparency of all aspects of the functioning of the sphere.

Previously we put forward the requirement of transparency in the framework of proposals to improve investment mechanisms in health care. In this context, the end-user of health transparency information was invited to be 
considered by the public and investors (Sledge, 2020). However, the criterion of transparency is valid for characterizing the dynamics of labour potential and production relations in the field. Transparency of political, legal, organizational and economic, personnel decisions for medical workers is necessary for personnel security in health care.

Building a long-term relationship of trust between public authorities and health workers will be the key to sustainable development by implementing mechanisms to overcome the problems relevant to the labour potential of health care.

According to the observation of the work of medical institutions, medical workers have a lot of innovative proposals, the consideration of which will help to improve the strategic and operational support of medical reform. Therefore, it is necessary to provide mechanisms for making appropriate proposals to the entities responsible for health care reform and provide incentives for health care professionals (Zarzewska-Bielawska, 2012).

Transparency in the functioning of organizational and economic mechanisms in health care will help eliminate the corruption component, as well as feelings of injustice and frustration among health workers who do not want to participate in corruption, which will have a significant motivating effect and prevent labour migration.

\section{DISCUSSION}

According to the study results, taking into account the theoretical foundations of health care in sustainable social development and identified in the preliminary analysis of the problems of the sphere, we propose to discuss several organizational and economic principles of growth and preservation of labour potential.

1. Improving the system of medical education. We found that the driving force for the transformation of the health care system is creating a health education system that meets European and international standards and can produce personnel focused on changes in health care and increase its overall effectiveness in the context of sustainable social development. Therefore, we propose to optimize the network of medical higher education institutions; bring to a high level their logistical and technological support by investing in fixed assets and staffing on the basis of cooperation with public authorities and local governments, foreign countries, medical institutions and medical universities; to integrate domestic medical education into the international system of medical education; to create preconditions for effective employment of graduates.

2. Monitoring of labour migration processes of medical staff. Given the lack of funding for health care, the issue of intersectoral and international occupational migration cannot be finally resolved. At the same time, at the present stage in the process of implementation of investment mechanisms of development, it is expedient to implement systems of monitoring of labour migration processes. Such a system will monitor migration dynamics, maintain dialogue with migrants and persons prone to migration, create conditions for the return of migrant workers with foreign experience.

3. Improving the systems of remuneration and motivation in the field of health care. Given the current state of limited resources, the simultaneous increase in wages for all health care workers will cause significant inflation. It will not comply with the principle of sustainable social development. Therefore, we consider it reasonable to recommend the development and implementation of a single objective rating system for assessing the staff of the health care system with a gradual increase in the budget of material incentives following the rating indicators and the implementation of intangible incentive programs.

4. Introduction of customer-oriented policy. It has been proven that the lack of significant competition in the field of health care and excessive workload and low level of material support lead to a low level of customer orientation of most state and municipal health care institutions. At the same time, the study found that the success of health care reforms depends on public support. Therefore, this framework proposes to create a mechanism to encourage customer-oriented practices in 
health care institutions, based on the interaction of feedback elements, the introduction of new information services, responding to the needs of clients and medical staff, conducting ethical training. As a result, it is expected to increase the trust and support of the population and increase the medical profession's prestige, which is one of the essential factors of intangible motivation.

5. Increasing the transparency of the sphere. To achieve personnel security in health care and support reforms by the medical staff, it is necessary to transparently cover organisational decision-making processes, particularly personnel decisions in the area. In addition, ensuring transparency will help eradicate corruption in the health sector and increase the involvement of health professionals in improving the efficiency of

\section{References}

Bachmann, S.-D. (2021). Mass Migration as a Hybrid Threat? - A Legal Perspective. Polish Political Science Yearbook, 50, 126. https://doi.org/10.15804/ppsy202122

Bodur, S. (2002). Job satisfaction of health care staff employed at health centres in Turkey. Occupational Medicine, 52(6), 353355. https://doi.org/10.1093/occmed/52.6.35 $\underline{3}$

Chauvin, S., Garcés-Mascareñas, B., \& Kraler, A. (2013). Employment and Migrant Deservingness. International Migration, 51(6), 8085. https://doi.org/10.1111/imig.12123

Chen, P.-C., \& Chi, N.-W. (2021). Serviceoriented human resource practices and customer outcomes: The service-profit chain perspective. Personnel Review, ahead-of-print(aheadof-print). https://doi.org/10.1108/PR-062020-0495

Chernenko Z., Teslenko V. (2013). Prava medychnykh pratsivnykiv $\mathrm{V}$ svitli reformy okhorony zdorovia. Analitychna zapyska HC4/2013.

URL: http://www.ier.com.ua/files/publications/Poli cy_Briefing_Series/2013/PB_04_2013_ukr.pdf (Аата звернення: 15.09.2018)

Cholewka, P. A., \& Motlagh, M. M. (Eds.). (2008). Health Capital and Sustainable Socioeconomic Development

ed.). the industry through the ability to monitor the results of their initiatives.

\section{CONCLUSIONS}

In this article, we have tried to cover several unresolved issues of preserving the labour potential of health care in Ukraine. We hope that the results of this article will allow us to look anew at ways to achieve the third goal of sustainable development in Ukraine and other countries with joint problems. The proposed recommendations may be partly idealistic, as governments need favourable conditions and, in some cases, additional funding to implement them. But, unfortunately, the current conditions of the pandemic are not ideal. So we hope that the health resources of Ukraine and other countries will be safe in the future.

Routledge. https://doi.org/10.1201/978142004 $\underline{6915}$

Cordell, G. (2011). Sustainable Medicines and Global Health Care. Planta Medica, 77(11), 1129-1138. https://doi.org/10.1055/s-0030$\underline{1270731}$

Dugani, S., Duke, T., \& Kissoon, N. (2016). Transforming health through sustainable development. Canadian Medical Association Journal, 188(10), E213E214. https://doi.org/10.1503/cmaj.151241

Fadhlurrohman, M. I., Purnomo, E. P., \& Malawani, A. D. (2020). Analysis Of Sustainable Health Development In Indonesia (Sustainable Development Goal's). Jurnal Kesehatan Lingkungan Indonesia, 19(2), 133143. https://doi.org/10.14710/ikli.19.2.133143

Harpham, T., \& Werna, E. (1996). Sustainable urban health in developing countries. Habitat International, 20(3), 421$429 . \quad$ https://doi.org/10.1016/01973975(96)00011-2

Hercog, M., \& Sandoz, L. (2018). Highly Skilled or Highly Wanted Migrants? Conceptualizations, Policy Designs and Implementations of High-skilled Migration Policies. Migration Letters, 15(4), 453460. https://doi.org/10.33182/ml.v15i4.534

Hjelm, K., Albin, B., Benato, R., \& Sourtzi, P. (2012). Migration and Health. Nursing 
Research and Practice, 2012, 12. https://doi.org/10.1155/2012/621914

Khomenko, K. Р. (2015). Порівняльний аналіз підготовки мікарів у Польщі та Україні. Педагогічні науки: теорія, історія, інноваційні технології. 2015. № 8. С. 226233.

Kulichenko, A., \& Boichenko, M. (2021). Origins of medical education on the territory of modern Ukraine. AD ALTA: Journal of Interdisciplinary Research, 11(1), 157161. https://doi.org/10.33543/1101157161

Liakhovskyi V., Kravtsiv M., Kravtsiv M. (2012). Вища медична освіта України i Болонський процес. Молодь і ринок.. № 4. C. 20-24

Mackay, R., \& Wolbring, G. (2013). Sustainable Consumption of Healthcare: Linking Sustainable Consumption with Sustainable Healthcare and Health Consumer Discourses. Proceedings of The 3rd World Sustainability Forum, i001. https://doi.org/10.3390/wsf3-i001

Mizhnarodnyi tsentr perspektyvnykh doslidzhen. (2006). Model hromadskoho kontroliu za vytratamy $\mathrm{v}$ sferi okhorony zdorovia. URL: http://icps.com.ua/assets/uploads/images/im ages/eu/budget_watch_healthcare_ukr.pdf (Аата звернення: 20.06.2018).

Motlhatlhedi, K., \& Nkomazana, O. (2018). Home is home-Botswana's return migrant health workers. PLOS ONE, 13(11), e0206969. https://doi.org/10.1371/journal.pon e.0206969

Ono, H., \& Kurono, Y. (2012). Cooperation among Pharmaceutical, Medical and Nursing Schools Aimed at 6-year Pharmaceutical Education. YAKUGAKU
ZASSHI, 132(1), 2129. https://doi.org/10.1248/yakushi.132.21

Rudiuk I.M., Lisun Ya.V. (2013). Upravlinnia pidpryiemstvom sfery posluh na osnovi kliientoriientovanoho pidkhodu. Ekonomichnyi rozvytok: teoriia, metodolohiia, upravlinnia: materialy Mizhnarodnoi naukovopraktychnoi konferentsii. Budapesht-ValensiiaKyiv,. S. 159-164.

Sepetis, A. (2020). Sustainable Finance in Sustainable Health Care System. Open Journal of Business and Management, 08(01), 262281. https://doi.org/10.4236/ojbm.2020.81016

Shevchuk V. V. (2014). Pidkhody do realizatsii mekhanizmiv derzhavnoho rehuliuvannia innovatsiinoho rozvytku systemy okhorony zdorovia Ukrainy. Naukovi pratsi [Chornomorskoho derzhavnoho universytetu imeni Petra Mohyly kompleksu "KyievoMohylianska akademiia"]. Ser. : Derzhavne upravlinnia.. T. 235, Vyp. 223. S. 128-132.

Singer, B. H., \& de Castro, M. C. (2007). Bridges to sustainable tropical health. Proceedings of the National Academy of Sciences, 104(41), 16038

16043. https://doi.org/10.1073/pnas.07009001 $\underline{04}$

Sledge, D. (2020). Considering the Role of Transparency in Health and Health Care. Hastings Center Report, 50(5), 4243. https://doi.org/10.1002/hast.1185

Zarzewska-Bielawska, A. (2012). The strategic dilemmas of innovative enterprises: Proposals for high-technology sectors: Strategic dilemmas of innovative enterprises. R\&D Management, 42(4), 303314. $\quad$ https://doi.org/10.1111/j.14679310.2012.00685.x 